\title{
Persepsi dan tingkat pengetahuan mahasiswa terhadap perkuliahan dalam jaringan di Progam Studi Pendidikan Geografi Universitas Negeri Malang
}

\author{
Achmad Alfinda Fadly, Alfariz Maulana Yusuf, Anggilia Widyaningsih, Devi Yuliyana Sari, \\ Dewi Sinta Azizah, Galih Rumpoko, Mc. Dohan Arrarrona, Nabila Munsyarikha, Tasyania \\ Izzah Salsabila, Satti Wagistina* \\ Universitas Negeri Malang, Jl. Semarang No. 5 Malang, Jawa Timur, Indonesia \\ *Penulis korespondensi, Surel: satti.wagisina.fis@um.ac.id
}

Paper received: 01-05-2021; revised: 15-05-2021; accepted: 30-05-2021

\begin{abstract}
This study aims to determine the perceptions and levels of student knowledge of online learning in the Department of Geography, State University of Malang. The impact of this pandemic affects existing learning activities. Learning activities that were initially carried out face-to-face, are now converted into networks (online). This certainly has an impact on students' perceptions and level of knowledge. This research uses quantitative method. This research has a total population of 450 with a sample of 100 and also the number of respondents as many as 100 students. Research data were collected from geography students at State University of Malang using a questionnaire that had been distributed using google form. The results of this study indicate that the perceptions and level of knowledge of students are included in online learning.
\end{abstract}

Keywords: perception; knowledge level; learning in networks

\begin{abstract}
Abstrak
Penelitian ini bertujuan untuk mengetahui bagaimana persepsi dan tingkat pengetahuan mahasiswa terhadap pembelajaran dalam jaringan di Program Studi Pendidikan Geografi Universitas Negeri Malang. Dampak dari adanya pandemi ini mempengaruhi kegiatan pembelajaran yang ada. Kegiatan pembelajaran yang awalnya dilakukan dengan tatap muka, kini dirubah menjadi dalam jaringan (dalam jaringan). Hal ini tentu berdampak pada persepsi dan tingkat pengetahuan mahasiswa. Penelitian ini menggunakan metode Kuantitatif. Penelitian ini memiliki jumlah populasi sebanyak 450 dengan sampel sebanyak 100 dan jumlah responden sebanyak 100 mahasiswa. Data penelitian dikumpulkan dari mahasiswa pendidikan geografi di Universitas Negeri Malang menggunakan angket yang telah dibagikan menggunakan google form. Hasil dari penelitian ini menunjukkan bahwa persepsi dan tingkat pengetahuan mahasiswa termasuk sedang dalam pembelajaran daring.
\end{abstract}

Kata kunci: persepsi; tingkat pengetahuan; pembelajaran dalam jaringan

\section{Pendahuluan}

Dewasa ini dimana terjadi penyebaran virus yang dikenal dengan Covid-19. Coronavirus Disease 2019 (Covid-19) merupakan jenis penyakit baru yang belum pernah diidentifikasi sebelumnya oleh manusia. Covid-19 kini tersebar di 215 negara di dunia. Dampak dari adanya pandemi ini mempengaruhi kegiatan pembelajaran yang ada. Kegiatan pembelajaran yang awalnya dilakukan dengan tatap muka, kini diubah menjadi dalam jaringan (dalam jaringan). Adanya perubahan pola kegiatan pembelajaran ini dikarenakan ketentuan dari pemerintah yang sudah dijelaskan pada Surat Edaran Kemendikbud Dikti No. 1 Tahun 2020. Faktanya kini semua Perguruan Tinggi telah melakukan kegiatan perkuliahan sudah dilakukan secara dalam jaringan. 
Pembelajaran dalam jaringan selalu melibatkan unsur teknologi (A. K. Putra, et al., 2021). Selain itu, pembelajaran dalam jaringan juga merupakan sebuah sistem pendidikan yang dilakukan secara jarak jauh dengan menggunakan metode pengajaran dimana kegiatan pengajaran dilakukan secara terpisah. Pada proses pembelajaran dalam jaringan mahasiswa dapat melakukan kegiatan pembelajaran dimanapun dan kapanpun. Walaupun pembelajaran dalam jaringan dapat dilakukan secara fleksibel, masih terdapat beberapa hal yang menimbulkan permasalahan dikalangan mahasiswa.

Permasalahan tersebut diantaranya pada tingkat pengetahuan mahasiswa. Banyak mahasiswa yang kurang bisa memahami materi yang disampaikan oleh dosen dikarenakan kegiatan pembelajaran tidak dilakukan secara langsung. Perbedaan pemahaman bahkan salah konsep pada materi sering ditemukan saat pembelajaran dalam jaringan berlangsung. Hal ini mampu menghambat tingkat pengetahuan dari tiap-tiap mahasiswa.

Diketahui bahwa perbedaan pemahaman tersebut juga berasal dari kemampuan mahasiswa. Terdapat mahasiswa yang mudah untuk terampil dalam belajar, proses berpikir sehingga memotivasi diri untuk mencapai tujuan belajar. Namun, juga terdapat mahasiswa yang kurang memiliki kemampuan untuk terampil dalam belajar hingga memotivasi diri untuk mencapai tujuan belajar. Hal ini dikarenakan pembelajaran dalam jaringan lebih mengutamakan proses pembelajaran yang dilakukan secara mandiri.

Pada umumnya kegiatan pembelajaran pada saat pembelajaran luar jaringan, dosen aktif dan selalu memberikan penjelasan dengan jelas dan minum untuk salah konsepsi saat penyampaian materi. Namun, pada kegiatan pembelajaran dalam jaringan dosen hanya memberikan materi-materi dan biasanya terdapat penjelasan, tetapi banyak mahasiswa yang salah memahami maksud dari materi yang telah disampaikan oleh dosen. Antara persepsi dan tingkat pengetahuan yang dimiliki oleh mahasiswa tentunya berbeda-beda.

Perubahan pola kegiatan belajar ini juga ada pada perguruan tinggi. Hal ini tentu berdampak pada persepsi dan tingkat pengetahuan mahasiswa. Persepsi merupakan sebuah pemahaman dimana melalui proses penginterpretasian stimulus yang diterima oleh panca indera (A. K. Putra, et al., 2021). Persepsi ini sangat penting pada kegiatan perkuliahan dalam jaringan karena persepsi akan menggerakan mahasiswa untuk dapat mengatur dan mengelola dirinya selama kegiatan pembelajaran. Sedangkan tingkat pengetahuan merupakan tingkatan seorang mahasiswa dalam mengingat serta memahami pada materi saat kegiatan perkuliahan telah dilakukan (Agarwal \& Kaushik, 2020). Dari kedua kaitan tersebut tentunya persepsi dan tingkat pengetahuan mahasiswa selama kegiatan perkuliahan dalam jaringan berbeda-beda terutama dalam mata kuliah Perencanaan Pembelajaran Geografi. Hal ini menjadi salah satu faktor utama dalam kegiatan penelitian ini. Tujuan dari penelitian ini adalah untuk memperoleh gambaran data mengenai persepsi dan tingkat pengetahuan mahasiswa selama kegiatan perkuliahan dalam jaringan di Program Studi Pendidikan Geografi Universitas Negeri Malang selama masa pandemi covid-19.

Derajat kemutakhiran bahan yang diacu dengan melihat proporsi 10 tahun terakhir dan mengacu pustaka primer. Permasalahan dan tujuan, serta kegunaan penelitian ditulis secara naratif dalam paragraf-paragraf, tidak perlu diberi subjudul khusus. Demikian pula definisi operasional, apabila dirasa perlu, juga ditulis naratif. 


\section{Metode}

Penelitian ini merupakan penelitian kuantitatif dengan model menggunakan pendekatan cross sectional. Penelitian dilakukan setelah mahasiswa melaksanakan pembelajaran dalam jaringan selama 3 bulan pada semester ganjil tahun ajaran 2020/2021. Penelitian ini dilakukan pada bulan November 2020 setelah dengan menggunakan angket dalam bentuk Google Form dan media Whatsapp untuk menyebarkan angket. Populasi pada penelitian ini adalah seluruh mahasiswa Prodi Pendidikan Geografi Fakultas Ilmu Sosial Universitas Negeri Malang. Sampel diambil dengan menggunakan teknik purposive sampling. Populasi dalam penelitian ini sebanyak 450 mahasiswa dengan sampel sebanyak 100 responden.

Penelitian persepsi yang digunakan melalui beberapa pendekatan seperti media yang digunakan, jenis komunikasi dan gaya belajar sementara tingkat pengetahuan yang tercakup dalam domain kognitif mempunyai 6 tingkatan, yaitu tahu (know), pemahaman (comprehension), aplikasi (application), analisis (analysis), sintesis (synthesis), dan evaluasi (evaluator). Pengukuran persepsi dan tingkat pengetahuan dilakukan dengan angket persepsi yang disusun dalam skala Likert dengan rentang jawaban sangat setuju (SS), setuju (S), tidak setuju (TS), dan sangat tidak setuju (STS).

Data yang dikumpulkan dalam penelitian ini adalah data primer yaitu data yang diperoleh langsung dari responden melalui pengisian kuesioner terstruktur. Teknik analisis data yang digunakan dalam penelitian ini adalah analisis kuantitatif yang terdiri atas pengumpulan data, reduksi data, penyajian data, dan penarikan kesimpulan.

\section{Hasil dan Pembahasan}

Adanya dampak dari Covid-19 adalah berubahnya pola kegiatan pembelajaran yang awalnya dilakukan secara tatap muka kini dilakukan secara dalam jaringan (daring). Hal ini dikarenakan untuk mencegah adanya persebaran virus Covid-19. Maka dari itu, pemerintah menghimbau untuk segala aktivitas diminimalisir bahkan pada perubahan kegiatan pembelajaran. Dari adanya kegiatan pembelajaran yang diubah, maka terdapat persepsi dari tiap-tiap mahasiswa yang berbeda-beda. Selain itu, tingkat pengetahuan pada mahasiswa juga berbeda diakibatkan kegiatan pembelajaran secara daring.

Persepsi merupakan kemampuan menerjemahkan stimulus yang ada di dalam dalam alat indera manusia. Tiap-tiap manusia memiliki persepsinya masing-masing. Terdapat seorang yang mempersepsikan hal tersebut baik dan ada pula seseorang yang mempersepsikan hal tersebut tidak baik. Hal tersebut akan mempengaruhi tindakan manusia yang dapat dilihat atau nyata dalam kehidupannya (Sugiharto, et al., 2007). Sedangkan tingkat pengetahuan merupakan cakupan yang ada pada ranah kognitif (Notoatmodjo, 2012).

Penelitian ini dilakukan dengan menyebarkan angket dan terdapat 2 pokok angket yaitu pertanyaan-pertanyaan mengenai persepsi dan pertanyaan mengenai tingkat pengetahuan. Dari persebaran angket tersebut selanjutnya di uji validitas dan reliabilitas yang ada pada tabel 1, 2, dan 3. Validitas sangat penting pada suatu instrument dikarenakan berkaitan dengan kemampuan instrumen untuk mengukur atau mengungkap karakteristik dari variabel yang akan diukur (Aritonang, 2008). 
Tabel 1. Validitas Persepsi Pembelajaran dalam Jaringan

\begin{tabular}{|c|c|c|c|c|c|c|c|c|c|c|}
\hline & P1 & P2 & P3 & $\mathrm{P} 4$ & P5 & P6 & P7 & P8 & P9 & P10 \\
\hline \multirow{2}{*}{ rHitung } & 0.775 & 0.76146 & 0.721 & 0.659 & 0.630 & 0.532 & 0.260 & 0.407 & 0.457 & 0.31 \\
\hline & 237 & 7139 & 717 & 552 & 596 & 306 & 414 & 034 & 733 & 8519 \\
\hline \multirow{2}{*}{ rTabel } & 0.165 & & 0.165 & 0.165 & 0.165 & 0.165 & 0.165 & 0.165 & 0.165 & 0.16 \\
\hline & 4 & 0.1654 & 4 & 4 & 4 & 4 & 4 & 4 & 4 & 54 \\
\hline $\mathrm{V} / \mathrm{T}$ & V & V & V & V & V & V & V & V & V & V \\
\hline
\end{tabular}

Hasil uji validitas pada pertanyaan-pertanyaan yang berada di angket persepsi menunjukkan bahwa dari 10 soal dikatakan valid. Hal ini diketahui bahwa hasil $r$ Hitung lebih besar daripada hasil rTabel (Riyanto, 2011). Hasil Hitung diperoleh dari pengolahan pada excel menggunakan rumus korelasi, sedangkan hasil $r$ Tabel diperoleh sebesar 0.1654 yang menunjukkan bahwa responden pada uji validitas ini sebesar 100 responden dengan taraf kepercayaan sebesar $5 \%$.

Tabel 2. Validitas Tingkat Pengetahuan

\begin{tabular}{|c|c|c|c|c|c|c|c|c|c|c|}
\hline & $\mathrm{P} 1$ & $\mathrm{P} 2$ & P3 & $\mathrm{P} 4$ & P5 & P6 & P7 & P8 & P9 & P10 \\
\hline \multirow{2}{*}{ rHitung } & 0.66 & 0.66937 & 0.62 & 0.551 & 0.671 & 0.72 & 0.775 & 0.765 & 0.697 & 0.48209 \\
\hline & 0112 & 6387 & 38 & 845 & 092 & 739 & 709 & 473 & 793 & 9 \\
\hline rTabel & $\begin{array}{l}0.16 \\
54\end{array}$ & 0.1654 & $\begin{array}{l}0.16 \\
54\end{array}$ & $\begin{array}{l}0.165 \\
4\end{array}$ & $\begin{array}{l}0.165 \\
4\end{array}$ & $\begin{array}{l}0.16 \\
54\end{array}$ & $\begin{array}{l}0.165 \\
4\end{array}$ & $\begin{array}{l}0.165 \\
4\end{array}$ & $\begin{array}{l}0.165 \\
4\end{array}$ & 0.1654 \\
\hline $\mathrm{V} / \mathrm{T}$ & V & V & $\mathrm{V}$ & V & V & $\mathrm{V}$ & V & V & V & V \\
\hline
\end{tabular}

Hasil uji validitas pada pertanyaan-pertanyaan yang berada di angket pengetahuan, menunjukkan bahwa 10 soal yang telah diuji validitasnya dikatakan valid. Hal ini dikarenakan hasil dari t Hitung lebih besar daripada r Tabel.

Tabel 3. Reliabilitas

\begin{tabular}{lll}
\hline & Persepsi & Tingkat Pengetahuan \\
\hline rac & 0.680022 & 0.857981803 \\
\hline
\end{tabular}

Reliabilitas dilakukan untuk mengetahui sejauh mana hasil dari suatu pengukuran memiliki keajegan, konsisten yang dapat dipercaya (Azwar, 2011). Hasil uji reliabilitas pada pertanyaan-pertanyaan yang berada di angket persepsi dan tingkat pengetahuan menunjukkan bahwa pada persepsi hasil reliabilitasnya tinggi dengan hasil 0,680022 hal ini dikarenakan berada pada antara 0,60-0,80 (Guilford, 1956). Sedangkan pada tingkat pengetahuan memiliki reliabilitas yang sangat tinggi dengan hasil 0,857981803 hal ini dikarenakan hasilnya berada di antara 0,80-1,00 (Guilford, 1956).

\subsection{Aplikasi yang digunakan selama Pembelajaran Dalam Jaringan}

Tabel 4. Penggunaan Aplikasi dalam Pembelajaran Dalam jaringan

\begin{tabular}{ll}
\hline Aplikasi & Presentase (\%) \\
\hline Whatsapp Grup & 8 \\
Google Meet & 30 \\
Google Classroom & 35 \\
Sipejar (E-learning UM) & 27 \\
\hline
\end{tabular}


Berdasarkan pemaparan Tabel 4 diperoleh hasil persentase penggunaan aplikasi paling besar dari aplikasi Google Classroom dengan nilai persentase sebesar 35\%, selanjutnya disusul oleh Google Meet dengan nilai persentase sebesar 30\%, dan yang ketiga disusul oleh aplikasi Sipejar (E-learning UM) dengan nilai persentase sebesar 27\%, dan penggunaan paling kecil diperoleh aplikasi Whatsapp Group dengan nilai persentase sebesar 8\%. Hal ini sangat sesuai mengingat penggunaan kedua aplikasi ini (Google Classroom dan Google Meet) dilakukan hampir setiap pelaksanaan perkuliahan.

\subsection{Persepsi Mahasiswa terhadap Pembelajaran Dalam Jaringan}

Tabel 5. Persentase Persepsi Responden Terhadap Pembelajaran dalam jaringan

\begin{tabular}{|c|c|c|c|c|c|}
\hline No & Pertanyaan & $\begin{array}{l}\text { STS } \\
(\%)\end{array}$ & $\begin{array}{l}\text { TS } \\
(\%)\end{array}$ & $\begin{array}{l}\text { S } \\
(\%)\end{array}$ & $\begin{array}{l}\text { SS } \\
(\%)\end{array}$ \\
\hline 1. & $\begin{array}{l}\text { Saya sangat tertarik dan antusias dengan metode } \\
\text { pembelajaran secara online. }\end{array}$ & 17 & 46 & 33 & 4 \\
\hline 2. & $\begin{array}{l}\text { Pembelajaran online membuat saya lebih } \\
\text { termotivasi untuk belajar. }\end{array}$ & 17 & 55 & 5 & 23 \\
\hline 3. & $\begin{array}{l}\text { Pembelajaran online membuat saya lebih terampil } \\
\text { dan dapat menemukan ide-ide baru. }\end{array}$ & 11 & 45 & 38 & 6 \\
\hline 4. & $\begin{array}{l}\text { Saya lebih memahami materi dengan model belajar } \\
\text { secara online. }\end{array}$ & 24 & 67 & 8 & 1 \\
\hline 5. & $\begin{array}{l}\text { Pembelajaran online membuat saya mengerjakan } \\
\text { tugas secara on time/tepat waktu. }\end{array}$ & 12 & 28 & 48 & 12 \\
\hline 6. & $\begin{array}{l}\text { Waktu pelaksanaan kegiatan pembelajaran online } \\
\text { lebih efektif dilakukan dari pada saat pembelajaran } \\
\text { tatap muka. }\end{array}$ & 24 & 43 & 26 & 7 \\
\hline 7. & $\begin{array}{l}\text { Pembelajaran online mengakibatkan sering } \\
\text { terjadinya perbedaan pendapat antara dosen dan } \\
\text { mahasiswa dalam menerjemahkan materi yang } \\
\text { diberikan. }\end{array}$ & 6 & 14 & 60 & 20 \\
\hline 8. & $\begin{array}{l}\text { Saya membuka aplikasi yang digunakan untuk } \\
\text { pembelajaran online (WA, Sipejar, Google } \\
\text { Classroom, google meeting, dan lain-lain) jika ada } \\
\text { tugas saja yang diberikan oleh guru. }\end{array}$ & 7 & 31 & 45 & 17 \\
\hline 9. & $\begin{array}{l}\text { Aplikasi yang digunakan saat berlangsungnya } \\
\text { kegiatan kelas online mudah diakses. }\end{array}$ & 3 & 18 & 70 & 9 \\
\hline
\end{tabular}

Penelitian ini menunjukkan bahwa (67\%) responden menyatakan tidak setuju bahwasannya dari model pembelajaran secara online membuat mahasiswa lebih memahami materi yang diberikan. Hal ini bisa disebabkan oleh keterbatasan dosen dalam penyampaian materi melalui forum belajar yang terbatas dari segi ruang sehingga dalam pelaksanaanya tidak berjalan secara efektif. Kegiatan pembelajaran yang dilakukan secara online cenderung menjadikan mahasiswa kurang menguasai dan memahami isi materi yang disampaikan. Kegiatan pembelajaran online yang telah dilakukan juga berdampak pada sering terjadinya perbedaan pendapat antara mahasiswa dengan dosen dalam menerjemahkan materi yang diberikan. Hal ini terlihat dari hasil penelitian yang menunjukkan (60\%) responden yang menyatakan setuju jika model pembelajaran online yang dilakukan menimbulkan perbedaan. Keadaan tersebut apabila tetap dibiarkan tentu akan berdampak pada motivasi mahasiswa dalam belajar. Hal ini terlihat dari hasil penelitian yang menunjukkan (55\%) responden menyatakan tidak setuju bahwasannya dari kegiatan pembelajaran online yang dilakukan 
dapat meningkatkan motivasi belajar dari mahasiswa. Selanjutnya pada penelitian ini menunjukkan bahwa pembelajaran online kurang efektif karena mahasiswa menjadi kurang terampil, hal ini ditunjukkan dengan hasil tanggapan responden yang menunjukkan angka $45 \%$ tidak setuju terhadap kuisioner "pembelajaran online membuat saya lebih terampil dan dapat menemukan ide baru".

\subsection{Tingkat Pengetahuan Mahasiswa terhadap Pembelajaran Dalam Jaringan}

Tabel 6. Persentase Tingkat Pengetahuan Mahasiswa terhadap Pembelajaran dalam jaringan

\begin{tabular}{|c|c|c|c|c|c|}
\hline No & Pernyataan & $\begin{array}{l}\text { STS } \\
(\%)\end{array}$ & $\begin{array}{l}\text { TS } \\
(\%)\end{array}$ & $\begin{array}{l}\text { S } \\
\text { (\%) }\end{array}$ & $\begin{array}{l}\text { SS } \\
(\%)\end{array}$ \\
\hline 1. & $\begin{array}{l}\text { Saya mengetahui arti tentang pembelajaran } \\
\text { dalam jaringan (daring) yang saat ini } \\
\text { dilakukan. }\end{array}$ & 3 & 13 & 73 & 11 \\
\hline 2. & $\begin{array}{l}\text { Saya mengetahui media apa saja yang dapat } \\
\text { menunjang kegiatan pembelajaran daring. }\end{array}$ & 2 & 5 & 79 & 14 \\
\hline 3. & $\begin{array}{l}\text { Saya memahami cara mengoperasikan aplikasi } \\
\text { pembantu dalam pembelajaran daring seperti } \\
\text { google classroom, web conference, WhatsApp } \\
\text { grup, sipejar, dan lainnya. }\end{array}$ & 1 & 2 & 74 & 23 \\
\hline 4. & $\begin{array}{l}\text { Saya mampu mengidentifikasi perbedaan dari } \\
\text { pembelajaran daring dan juga pembelajaran } \\
\text { luring. }\end{array}$ & 1 & 4 & 81 & 14 \\
\hline 5. & $\begin{array}{l}\text { Kegiatan pembelajaran daring melatih saya } \\
\text { untuk lebih mandiri dalam memecahkan soal } \\
\text { terkait materi yang diberikan }\end{array}$ & 2 & 23 & 63 & 12 \\
\hline 6. & $\begin{array}{l}\text { Dengan adanya kegiatan pembelajaran daring } \\
\text { membuat pemahaman saya terhadap materi } \\
\text { semakin meningkat. }\end{array}$ & 13 & 67 & 17 & 3 \\
\hline 7. & $\begin{array}{l}\text { Dengan adanya kegiatan pembelajaran secara } \\
\text { daring mampu meningkatkan kemampuan } \\
\text { mengevaluasi terhadap materi yang diberikan. }\end{array}$ & 6 & 50 & 39 & 5 \\
\hline 8. & $\begin{array}{l}\text { Dengan adanya kegiatan pembelajaran daring } \\
\text { mampu meningkatkan kemampuan analitis } \\
\text { saya terhadap materi yang disampaikan. }\end{array}$ & 5 & 49 & 41 & 5 \\
\hline 9. & $\begin{array}{l}\text { Kemampuan sintesis saya terhadap materi } \\
\text { yang diberikan selama pembelajaran daring } \\
\text { menjadi meningkat. }\end{array}$ & 6 & 56 & 34 & 4 \\
\hline 10. & $\begin{array}{l}\text { Saya mampu menghasilkan suatu produk } \\
\text { seperti jurnal, artikel, karya ilmiah dan lainnya } \\
\text { selama kegiatan pembelajaran daring. }\end{array}$ & 2 & 30 & 58 & 10 \\
\hline
\end{tabular}

Berdasarkan data survei yang dilakukan diperoleh informasi tingkat pengetahuan tentang perkuliahan dalam jaringan bahwa sebanyak 80\% mahasiswa kurang mampu memahami pembelajaran dengan baik. Sedangkan sisanya yaitu 20\% mahasiswa mampu memahami materi pembelajaran yang diberikan. Berikut ini adalah diagram mengenai Kemampuan mahasiswa.

Kurang mampunya mahasiswa di dalam memahami materi dikarenakan kurang efektifnya pembelajaran dalam jaringan. Sehingga, mahasiswa kurang dapat mencerna materi pembelajaran yang diberikan oleh dosen. Hal itu juga didukung oleh tidak mampunya 
mahasiswa di dalam mengevaluasi materi yang didapat, dan kurang mampunya mahasiswa untuk menganalisis materi yang didapatkan.

Berdasarkan hasil survey yang dilakukan diketahui sebanyak 56\% mahasiswa tidak mampu mengevaluasi terhadap materi yang didapatkan. Oleh karena itu, hal ini berakibat terhadap kurang mampunya mahasiswa di dalam memahami materi yang disampaikan oleh dosen melalui kegiatan pembelajaran dalam jaringan. Selain dari kemampuan evaluasi mahasiswa juga merasa kurang mampu untuk meningkatkan kemampuan analisisnya. Hal ini sesuai dengan hasil survey yang menunjukkan sebanyak 54 mahasiswa tidak mampu untuk menganalisis materi yang telah disampaikan. Sedangkan sisanya yaitu 46\% mahasiswa.

Tabel 7. Persentase Persepsi mahasiswa terhadap pembelajaran daring

\begin{tabular}{ll}
\hline Kategori & Presentase (\%) \\
\hline Buruk & 12 \\
Sedang & 73 \\
Baik & 15 \\
\hline
\end{tabular}

Berdasarkan data hasil angket dibuat kategori menggunakan standar deviasi dan ratarata nilai untuk tingkat persepsi yaitu untuk kategori bernilai Buruk: $\mathrm{X}<18$, Sedang :18<=X< 26, Baik:X >=26 kemudian ditransformasi menggunakan SPSS menunjukkan pada Tabel 4. bahwa $12 \%$ mahasiswa memiliki persepsi buruk terhadap pembelajaran daring, kemudian 73\% mahasiswa memiliki persepsi sedang terhadap pembelajaran daring dan $15 \%$ mahasiswa memiliki persepsi baik terhadap pembelajaran daring. Dari hasil kategori persepsi mahasiswa menunjukkan bahwa rata-rata mahasiswa memiliki persepsi sedang terhadap pembelajaran daring di Program Studi Pendidikan Geografi Universitas Negeri Malang.

Tabel 8. Persentase Tingkat Pengetahuan Mahasiswa

\begin{tabular}{ll}
\hline Kategori & Presentase (\%) \\
\hline Rendah & 13 \\
Sedang & 79 \\
Tinggi & 8 \\
\hline
\end{tabular}

Berdasarkan data hasil angket dibuat kategori menggunakan standar deviasi dan ratarata skor angket untuk tingkat persepsi yaitu untuk kategori bernilai Rendah: $\mathrm{X}<23$.2, Sedang $: 23,2<=X<31.2$, Tinggi: $X>=31.2$ kemudian ditransformasi menggunakan SPSS menunjukkan pada Tabel 9. bahwa 13\% mahasiswa memiliki tingkat pengetahuan rendah ketika menggunakan pembelajaran daring, kemudian 79\% mahasiswa memiliki tingkat pengetahuan sedang ketika menggunakan pembelajaran daring dan 8\% mahasiswa memiliki tingkat pengetahuan tinggi ketika menggunakan pembelajaran daring. Dari hasil kategori tingkat pengetahuan mahasiswa menunjukkan bahwa rata-rata mahasiswa memiliki tingkat pengetahuan sedang ketika menggunakan pembelajaran daring di Program Studi Pendidikan Geografi Universitas Negeri Malang.

\section{Simpulan}

Penelitian persepsi dan tingkat pengetahuan ini terdapat 100 responden mendapatkan taraf kepercayaan sebesar 5\% dan hasil ini bisa dikatakan valid. Untuk validitas tingkat 
pengetahuan menunjukkan bahwa hasil yang diperoleh valid berdasarkan 10 soal yang telah diuji. Untuk reliabilitas digunakan untuk mengetahui keajegan dari hasil sebuah pengukuran, dan dalam penelitian yang dilakukan menunjukkan persepsi memperoleh hasil reliabilitas tinggi dengan nilai 0,680022 , sedangkan untuk tingkat pengetahuan memperoleh hasil yang tinggi dengan nilai 0,857981803 . Berdasarkan hasil penelitian maka persepsi mahasiswa tergolong dalam kategori sedang, kemudian pada tingkat pengetahuan tergolong dalam kategori sedang.

\section{Daftar Rujukan}

Agarwal, S., \& Kaushik, J. S. (2020). Student's perception of online learning during COVID pandemic. The Indian Journal of Pediatrics, 87, 554-554.

Aritonang, L. (2008). Validitas dan Reliabilitas Butir Instrumen. Jakarta: Akademika.

Azwar, S. (2011). Reliabilitas dan Validitas. Yogyakarta: Pustaka Pelajar.

Gulford, J.P. (1956). Fundamental Statistic in Psychology and Education. New York: McGraw-Hill Book Company, Inc.

Notoatmodjo, S. (2012). Metode Penelitian Kesehatan. Jakarta: PT. Rineka Cipta.

Putra, A. K., Irawan, L. Y., Deffinika, I., Fahmi, A., \& Tanjung, A. (2021, March). Knowledge and participation of geography teachers toward flood disaster risk reduction in sampang indonesia. In IOP Conference Series: Earth and Environmental Science (Vol. 683, No. 1, p. 012029). IOP Publishing.

Ramadhani, R. M., Gustaman, F. A. I., Kodar, M. S., \& Widanaha, I. K. (2020). Implementasi Program Sekolah Aman Bencana di Sekolah Menengah Kejuruan Negeri 4 Balikpapan Kalimantan Timur. JIPSINDO, 7(2), 102-118.

Riyanto, A. (2011). Aplikasi Metodologi Penelitian Kesehatan. Yogyakarta: Nuha Medika.

Sugiharto, S., et al. (2007). Teori Tentang Pengertian Persepsi. Jakarta: Yayasan Kanisius. 